\title{
Gastrointestinal hormone mRNA expression in human colonic adenocarcinomas, hepatic metastases and cell lines
}

G Monges, P Biagini, J F Cantaloube, P De Micco, D Parriaux, J F Seitz, J R Delpero, $\mathrm{J}$ Hassoun

\section{Laboratory of \\ Anatomical Pathology, \\ Paoli Calmettes \\ Institute, \\ 232 Boulevard de \\ Sainte Marguerite, \\ 13009 Marseille, \\ France \\ $\mathrm{G}$ Monges \\ D Parriaux \\ J Hassoun \\ Department of \\ Oncology \\ J F Seitz \\ J R Delpero \\ Laboratory of \\ Molecular Biology, \\ Regional Centre for \\ Blood Transfusion, \\ 149 Boulevard Baille, \\ 13005 Marseille, \\ France \\ P Biagini \\ J F Cantaloube \\ P De Micco \\ Correspondence to: \\ Dr G Monges.}

Accepted for publication 28 March 1996

\begin{abstract}
Aims-(1) To investigate the expression of the four main hormones of the digestive tract by performing reverse transcription polymerase chain reaction (RT-PCR) on a series of samples, comprising tumoral and healthy colonic tissues, hepatic metastases and colonic cell line samples; and (2) to study the patterns of labelling obtained with serological and morphological markers.

Methods-After extraction and reverse transcription, gastrin, somatostatin, cholecystokinin (CCK) and transforming growth factor $\alpha(T G F \alpha)$ mRNAs were detected by PCR and nested PCR using specific primers. The corresponding proteins were detected by immunohistochemistry.

Results-The cell lines expressed all four mRNAs. Gastrin mRNA was present in most tumoral and metastatic samples, while the somatostatin transcript was detected in all samples and was frequently overexpressed in the normal colon. TGF $\alpha$ mRNA was expressed systematically in tumours of the right and transverse colon, but not in those located in the left colon; the expression of CCK mRNA was systematically absent in the left colon.

Conclusions-The data presented here shed some light on the transcriptional events involved in the production of the various hormones present in the gastrointestinal tract, in both healthy and tumoral tissues. The various mRNAs expressed in cell lines are therefore not systematically expressed in the human pathology.

(F Clin Pathol: Mol Pathol 1996;49:M159-M165)
\end{abstract}

Keywords: gastrin, somatostatin, cholecystokinin, TGF $\alpha$, colonic adenocarcinoma, PCR, immunohistochemistry.

The growth of the normal gastrointestinal mucosa, as well as that of tumours of the gastrointestinal tract, is regulated by numerous hormones and growth factors. ${ }^{1}$

Gastrin is an essential hormone which is present in the stomach (antrum) of adult humans; it is known to play a leading role in the secretion of gastric juice and promotes the growth of gastrointestinal epithelial cells. ${ }^{3}$ It has been established both in vivo and in vitro that it acts as a hormonal activator stimulating many gastrointestinal cancers. ${ }^{4-7}$

Somatostatin and cholecystokinin (CCK) are also among the main hormonal mediators contributing to the trophicity of the digestive tract, probably by participating in the regulation of gastrin synthesis. ${ }^{6-12}$

Transforming growth factor $\alpha$ (TGF $\alpha$ ), which has an autocrine and paracrine action, also has regulatory effects on both growth and digestion in the gastrointestinal tract. ${ }^{13}$ The results of several studies have suggested that TGF $\alpha$ may act as an autocrine growth factor for several colon cancer cell lines. ${ }^{14}{ }^{15}$

Although the effects and modes of action of these hormones have been determined at the peptide level, the modes of expression of their mRNAs have not been fully elucidated in both healthy and tumoral tissues.

Most of the data available currently were derived from cell lines, where some coexpression of these hormones has been observed. In a study on colonic carcinoma cell lines-for example, gastrin and TGF $\alpha$ were coexpressed. ${ }^{14}$ Gastrin and CCK were found to be coexpressed in a gastric carcinoma cell line. ${ }^{16}$ The gastrin transcript, which has been studied particularly thoroughly, was also detected in surgical specimens ${ }^{17-19}$ and in paraffin wax embedded samples. ${ }^{20}$

The aim of the present study was to investigate the coexpression of gastrin, somatostatin, CCK and TGF $\alpha$ mRNAs in both colonic tumours and the corresponding healthy tissue. Hepatic metastases and colon cancer cell lines were also tested. The presence of the corresponding proteins was detected using immunohistochemical methods. We also examined whether there was any correlation between expression of these mRNAs, their serological concentrations and the staining pattern obtained by immunohistochemistry.

\section{Methods}

The stage of each tumour examined was assessed according to the Astler and Coller classification. ${ }^{21}$ The localisation of the tumour in the colon was noted.

SERUM GASTRIN CONCENTRATIONS

Blood was collected in the morning from fasting patients who were not undergoing drug treatment; gastrin concentrations were measured using a commercial radioimmunoassay kit (GASK-PR, Cis Bioindustries, Gif-surYvette, France), as described previously. ${ }^{18}$ 
Table 1 Primers used

\begin{tabular}{ll}
\hline Hormone & Primer sequence \\
\hline Gastrin $^{23}$ & GAS 1: 5' TAT GTG CTG ATC TTT GCA CTG GCT 3' (sense: 6307-6330) \\
& GAS 2: 5' CTC ATC CTC AGC ACT GCG GCG GCC 3' (antisense: 6718-6695) \\
Somatostatin $^{24}$ & GAS 3: 5' GAG CTA CCC TGG CTG GAG CAG CAG 3' (sense: 6415-6438) \\
& SOM 1: 5' ATG CTG TCC TGC CGC CTC CAG 3' (sense: 106-126) \\
& SOM 2: 5' ACA GGA TGT GAA AGT CTT CCA 3' (antisense: 1330-1310) \\
Cholecystokinin $^{25}$ & SOM 3: 5' GCT GCT GCC GCG GGG AAG CAG 3' (sense: 223-243) \\
& CCK 1: 5' ATG AAC AGC GGC GTG TGC CTG 3' (sense: 1279-1299) \\
& CCK 2: 5' GGA GGG GTA CTC ATA CTC CTC 3' (antisense: 6808-6788) \\
${\text { TGF }{ }^{26}}^{26}$ & CCK 3: 5' AGA TAC ATC CAG CAG GCC CGG 3' (sense: 1468-1488) \\
& TGF 1: 5' ATG GTC CCC TCG GCT GGA CAG 3' (sense: 35-55) \\
& TGF 2: 5' GAC CAC TGT TTC TGA GTG GCA 3' (antisense: 514-494) \\
& TGF 3: 5' CCA GCA TGT GTC TGC CAT TCT 3' (sense: 239-259) \\
\end{tabular}

EXTRACTION OF RNA

Surgical specimens

RNA was extracted from 10 human colon tumours, 10 normal colonic mucosal samples, seven hepatic metastases, and two antral and one fundic gastric mucosal sample, as described by Monges et al. ${ }^{18}$ Briefly, the tissue samples $(2 \mathrm{~g})$ were stored at $-80^{\circ} \mathrm{C}$, pulverised in liquid nitrogen and homogenised in a buffer containing $50 \%$ guanidine thiocyanate, $0.5 \%$ sodium $\mathrm{N}$-lauroylsarcosinate, $5 \mathrm{mM}$ sodium citrate, and $0.1 \mathrm{M} \beta 2$-mercaptoethanol. The RNA was then recovered by ultracentrifugation and any remaining traces of DNA were removed using the guanidiniumphenol-chloroform method. ${ }^{22}$ The resulting RNA pellets were finally resuspended in $100 \mu \mathrm{l}$ diethyl pyrocarbonate (DEPC) treated sterile water.

\section{Cell lines}

RNA was extracted from four colonic carcinoma cell lines: $\mathrm{CaCo} 2$, Sk-Co15, HT-2918 glu, and HT-29.18 gal. Cells were grown in serum free media, harvested with rubber policemen, washed twice in phosphate buffered saline (PBS), and centrifuged slowly. Cell pellets were placed in DEPC lysis buffer (20 $\mathrm{mM}$ Tris $\mathrm{HCl}(\mathrm{pH} \mathrm{8.0)/20} \mathrm{mM} \mathrm{EDTA} \mathrm{(pH}$ $8.0) / 2 \% \mathrm{SDS} / 500 \mu \mathrm{g} / \mathrm{ml}$ proteinase $\mathrm{K}$ ) and incubated for 24 hours at $50^{\circ} \mathrm{C}$. The solutions were then treated using the guanidiniumphenol-chloroform method.

RT-PCR OF MRNA

RNA (3.5 $\mu \mathrm{g})$ was reverse transcribed using an oligo-dT primer (Boehringer Mannheim, Meylan, France) and 20 units of Moloney Murine Leukaemia Virus reverse transcriptase (Boehringer Mannheim) in a reaction volume of $20 \mu \mathrm{l}$. This cDNA was used as a template in the PCR assay.

The following were used in each PCR assay, in a total volume of $50 \mu \mathrm{l}: 5 \mu \mathrm{l} \mathrm{cDNA} ; 500 \mathrm{M}$ of each deoxynucleotide triphosphate (Pharmacia, St. Quentin en Yvelines, France); $0.8 \mu \mathrm{M}$ of each specific primer (table 1); 1.5 units Taq DNA polymerase (Perkin Elmer, Roissy, France); $1 \times$ Taq DNA polymerase synthesis buffer (Perkin Elmer).

The choice of primers was optimised using a specialised program (Oligo 4.0, Eurogentec, Liege, Belgium).

The "hot start" procedure was carried out systematically by adding Taq polymerase to the reaction mixtures overlaid with mineral oil after 10 minutes of denaturation at $95^{\circ} \mathrm{C}$. PCR reactions conditions were as follows: denaturation at $95^{\circ} \mathrm{C}$ for 30 seconds, annealing at $60^{\circ} \mathrm{C}$ (gastrin/somatostatin) or $55^{\circ} \mathrm{C}(\mathrm{CCK} /$ TGF $\alpha$ ) for 30 seconds, and polymerisation at $72^{\circ} \mathrm{C}$ for 45 seconds for 30 cycles, with an additional 10 minute incubation period at $72^{\circ} \mathrm{C}$ after the final extension.

\section{NESTED PCR}

A $2 \mu l$ aliquot of the first PCR product was amplified again under the same conditions, except that the sense primer was replaced by an internal sense oligonucleotide (table 1). Because of the inherent sensitivity of PCR, the appropriate measures for minimising contamination ${ }^{27}$ were used in each assay.

ANALYSIS OF PCR PRODUCTS

The amplified products $(10 \mu \mathrm{l})$ were electrophoresed through $2 \%$ agarose gels in Trisborate/EDTA buffer, stained with ethidium bromide and viewed under ultraviolet light. ${ }^{28}$ The expected PCR products are given in table 2 .

Table 2 Expected PCR products (bp)

\begin{tabular}{llll}
\hline & $\begin{array}{l}\text { Single PCR } \\
\text { (primers } \\
1+2)\end{array}$ & $\begin{array}{l}\text { Nested PCR } \\
\text { (primers } \\
3+2)\end{array}$ & Intron \\
\hline Gormone & 282 & 174 & 130 \\
Gastrin & 348 & 231 & 877 \\
Comatostatin & 345 & 156 & 5000 \\
TGF $\alpha$ & 480 & 276 & 7000 \\
\hline
\end{tabular}

CONTROLS

To ensure that all of the RNA samples were intact, PCR was systematically carried out on the RNA of the cellular enzyme glyceraldebyde 3-phosphate dehydrogenase (G3PDH), as recommended by the manufacturer (Clontech G3PDH control kit; Ozyme, Montigny-leBretonneux, France)

\section{IMMUNOHISTOCHEMISTRY}

Fixed sections of the corresponding surgical specimens tested by PCR were immunostained using five polyclonal antibodies directed against: gastrin G17 (diluted 1 in 150; Eurodiagnostic, France); gastrin G17-G34 (diluted 1 in 25, Biogenesis, France); CCK/gastrin (diluted 1 in 20; Biogenesis); somatostatin (diluted 1 in 600; Dako, France); and TGF $\alpha$ (diluted 1 in 20; Oncogene Sciences, France).

Sections were also stained for Grimelius, and immunostained for chromogranin A (prediluted; Immunotech, France) to detect potential endocrine cells. 


\begin{tabular}{|c|c|c|c|c|c|c|c|c|c|c|}
\hline \multirow[b]{2}{*}{ Demographic details } & \multicolumn{10}{|c|}{ Case number (colonic adenocarcinoma) } \\
\hline & 4 & $5^{*}$ & 6 & 7 & 8 & 9 & 10 & 11 & 12 & 13 \\
\hline Sex & $\mathrm{F}$ & $\mathbf{M}$ & $\mathbf{M}$ & $\mathrm{F}$ & $M$ & $\mathrm{~F}$ & $M$ & $\mathrm{~F}$ & $\mathrm{~F}$ & $\mathbf{M}$ \\
\hline Age (years) & 48 & 60 & 68 & 55 & 67 & 68 & 68 & 48 & 51 & 79 \\
\hline Tumour site in colon & Right & Left & Left & Right & Left & Left & Left & Trans & Right & Trans \\
\hline Astler and Coller grade & $\mathrm{D}$ & $\mathrm{D}$ & $\mathrm{D}$ & $\mathrm{D}$ & $\mathrm{D}$ & $\mathrm{D}$ & $\mathrm{D}$ & B2 & $\mathrm{C} 2$ & $\mathrm{D}$ \\
\hline Differentiation & $\mathrm{W}$ & $\mathrm{W}$ & $\mathrm{M}$ & $\mathrm{W}$ & $M$ & $\mathrm{~W}$ & $M$ & W & W & $\mathrm{P}$ \\
\hline Ploidy & Near D & AN & AN & AN & AN & $\mathrm{D}$ & ND & M & AN & AN \\
\hline Basal gastrinaemia (mIU/l) & 159 & 34 & ND & 35 & 31 & 62 & 20 & 20 & $\mathrm{ND}$ & 66 \\
\hline Survival (months) & 14 & 23 & $35 t$ & $4 \dagger$ & 30 & 46 & 6 & 5 & $15 \dagger$ & $3 t$ \\
\hline
\end{tabular}

$\mathrm{ND}=$ not determined.

*Developed after ureterostomy (bullet wound sustained 10 years previously).

†Dead.

Trans $=$ Transverse colon $; \mathrm{W}=$ Well $; \mathrm{M}=$ Moderate $\mathrm{P}=$ Poorly $; \mathrm{D}=\operatorname{diploid} ; \mathrm{AN}=$ aneuploid $\mathrm{M}=$ mixed

\section{Results}

GASTRIN CONCENTRATIONS

Fasting plasma gastrin concentrations were measured in eight of the 10 patients (table 3) The values were nearly normal in five patients and slightly above normal in two (cases 9 and 13). One patient had hypergastrinaemia (case 4).

PCR

The mRNAs of all four gastrointestinal hormones were detected in the four cell lines. The gastrin transcript was readily detected in the first PCR run in the antral mucosal samples. Somatostatin mRNA was detected in antral samples, in fundic mucosa and in nine of the 10 normal colonic samples (no visible product in case 9) (data not shown). No CCK and $\mathrm{TGF} \alpha$ transcripts were detected in this first amplification step.

NESTED PCR

The presence of the four mRNAs was confirmed in all four cell lines; all four mRNA transcripts were detected in the antral mucosal samples (table 4). Gastrin mRNA was not detected in the fundic mucosa, whereas the other three transcripts were.
Gastrin mRNA was detected in nine of the 10 colonic adenocarcinomas and in five of the seven samples of hepatic metastasis; it was never detected in any of the 10 normal colonic samples.

Somatostatin mRNA was detected in normal colonic samples, colonic adenocarcinomas and in all samples of hepatic metastasis. Cases 6 and 7, however, exhibited shorter PCR products, which were detected using primers 1 and 2 with the nested PCR procedure.

Cholecystokinin mRNA was detected in four of the 10 normal colonic samples, in three of the 10 tumoral samples and in one of the seven samples of hepatic metastasis. TGF $\alpha$ mRNA was detected in seven of the 10 normal colonic samples, in six of the 10 tumoral samples and in six of the seven samples of hepatic metastasis.

Examples of these amplifications are given in figs $1-3$.

The G3PDH control assay was always positive (data not shown). In addition, each sample was positive at least once with a given transcript, which confirms that the RNA samples tested were intact.

Figure 1 Nested PCR amplification of RNA extracted from colonic carcinoma cell lines: HT 29.18 glu is shown here as an example. Identical results were obtained with the other cell lines. $M=$ relevant standards (markerVI, Boehringer Mannheim) in increasing order of size (bp): 154, 234, 298, 394, 453, 517, and 653 
Table 4 Expression of gastrin, somatostatin, CCK and TGF $\alpha$ mRA detected by nested PCR in surgical samples

\begin{tabular}{|c|c|c|c|c|c|c|c|c|c|c|c|c|c|c|c|}
\hline \multirow[b]{2}{*}{ Case number } & \multirow{2}{*}{$\begin{array}{l}\text { Tumour site } \\
\text { in colon }\end{array}$} & \multicolumn{2}{|c|}{ Endocrine cells } & \multicolumn{4}{|c|}{ Normal } & \multicolumn{4}{|c|}{ Tumour } & \multicolumn{4}{|c|}{ Hepatic metastasis } \\
\hline & & Grimelius & Chromogranin & $G$ & $S$ & $C C K$ & $T G F \alpha$ & $G$ & $S$ & $C C K$ & $T G F \alpha$ & $G$ & $S$ & $C C K$ & $T G F \alpha$ \\
\hline 10 & Left & 0 & 0 & 0 & $\star$ & * & 0 & $\star$ & * & 0 & * & 0 & * & * & $\star$ \\
\hline 8 & Left & 0 & 0 & 0 & $\star$ & $\star \star$ & 0 & $\star$ & $\star$ & 0 & 0 & $\star$ & $\star$ & 0 & $\star$ \\
\hline 6 & Left & 0 & 0 & 0 & $\star$ & * & 0 & $\star$ & * & 0 & 0 & $\star$ & $\star$ & 0 & * \\
\hline 5 & Left & 0 & 0 & 0 & $\star$ & 0 & $\star$ & 0 & $\star$ & 0 & 0 & 0 & $\star$ & 0 & * \\
\hline 9 & Left & 0 & 0 & 0 & $\star$ & 0 & * & $\star$ & * & 0 & 0 & $\star$ & * & 0 & 0 \\
\hline 7 & Right & $<1 / 100$ & $<1 / 100$ & 0 & $\star$ & $\star$ & * & $\star$ & * & 0 & 夫 & $\star$ & $\star$ & 0 & $\star$ \\
\hline 4 & Right & $<1 / 100$ & $<1 / 100$ & 0 & $\star$ & 0 & * & $\star$ & $\star$ & $\star$ & $\star$ & $\star$ & $\star$ & 0 & $\star$ \\
\hline 12 & Right & $1-5 / 100$ & $1-5 / 100$ & 0 & $\star$ & 0 & $\star$ & $\star$ & * & $\star$ & * & & - & & \\
\hline 11 & Transverse & 0 & 0 & 0 & $\star$ & 0 & * & $\star$ & * & 0 & * & & - & & \\
\hline 13 & Transverse & 0 & 0 & 0 & $\star$ & 0 & $\star$ & $\star$ & * & $\star$ & * & & ND & & \\
\hline $1(\mathrm{~A})$ & - & Positive† & Positive & $\star$ & $\star$ & $\star$ & * & & - & & & & - & & \\
\hline 2 (A) & - & Positivet & Positive & $\star$ & $\star$ & $\star$ & $\star$ & & - & & & & - & & \\
\hline $3(F)$ & - & Positivef & Positive & 0 & $\star$ & $\star$ & * & & - & & & & - & & \\
\hline
\end{tabular}

$\mathrm{G}=$ gastrin; $\mathrm{S}=$ somatostatin; $\mathrm{ND}=$ not determined.

*Positive nested PCR; 0 = negative nested PCR.

†Positive cells in normal ratio.

IMMUNOHISTOCHEMISTRY

All samples were negative, except for two antral mucosal samples (positive controls) which showed some reactivity to all five polyclonal antibodies tested, and for cases 4, 12 and 13 which showed TGF $\alpha$ immunostaining in some isolated cells of both normal and diseased colon (data not shown).

On staining for Grimelius and chromogranin A, scanty isolated positive cells were detected in the three colonic adenocarcinomas of the right colon (table 4).

\section{Discussion}

It has been established previously that gastrin acts as a growth factor and promotes the growth of human colon cancers, ${ }^{29}$ although the molecular mechanisms underlying its action have not been elucidated as yet. Moreover, the expression of the gastrin gene may be coupled to cellular events involved in the transformation of the colonic epithelium. ${ }^{19}$ The determinants of this coupling are not known, but they might include the transcriptional activation of the gastrin gene by epidermal growth factor (EGF) and $T G F \alpha$, which may also promote the growth of colon carcinomas. It has been suggested that TGF $\alpha$ may be an autocrine growth factor in colon cancers ${ }^{30}$ and that TGF $\alpha$ autocrine activity contributes to the progression of tumorigenic properties of human cancer cells in the absence of changes in growth. ${ }^{31}$ Little is known about the role of $\mathrm{CCK}$ and somatostatin in gastrointestinal cancers. As CCK peptides are known to be trophic factors in pancreatic growth, pancreatic cell
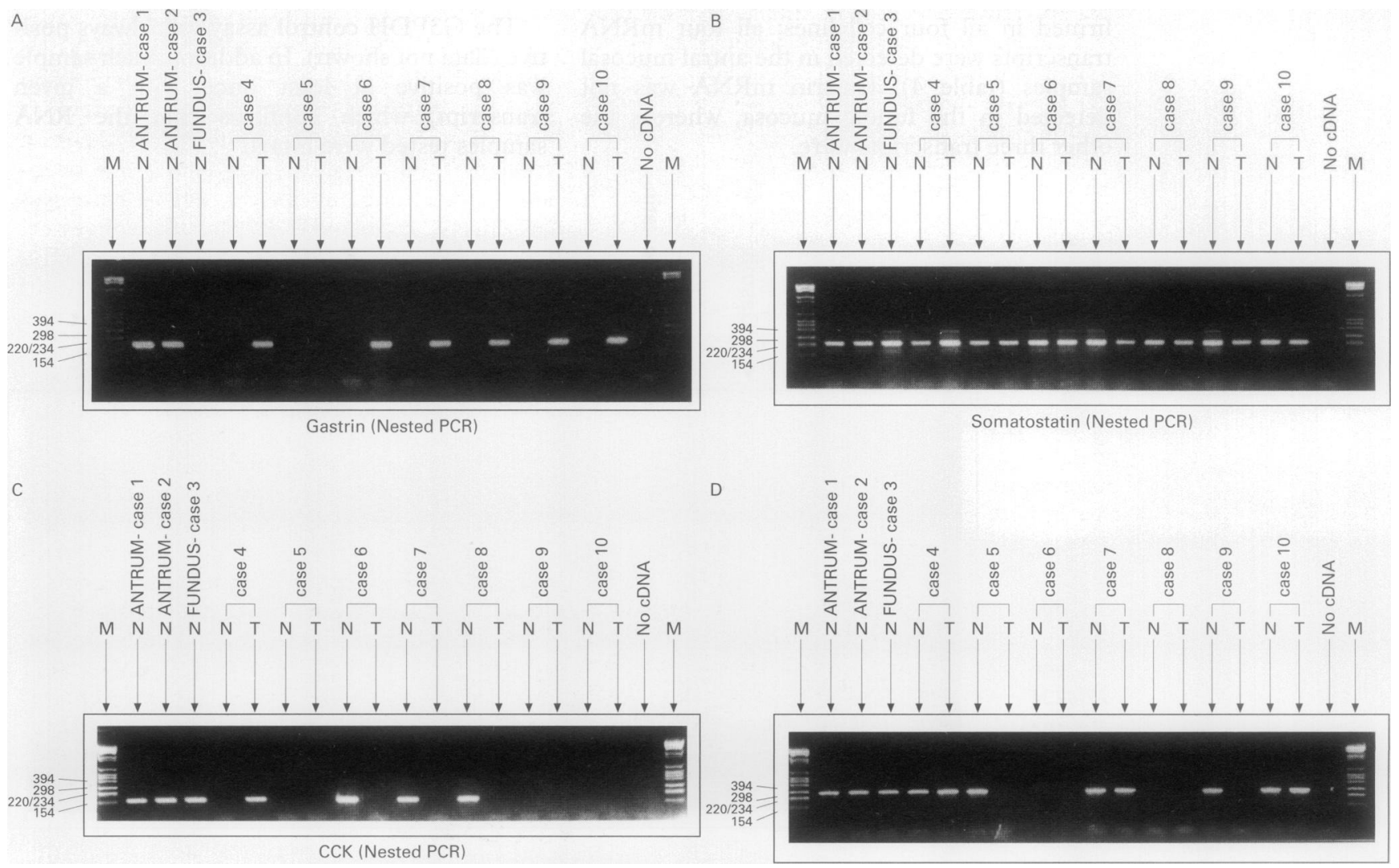

TGF $\alpha$ (Nested PCR)

Figure 2 Nested PCR on normal and tumoral colonic samples (cases 1 to 10 shown) to detect expression of $(A)$ gastrin, $(B)$ somatostatin, (C) CCK, and (D) TGF $\alpha$ RNA. $N=$ normal colon; $T=$ colonic tumour; $M$ = size markers (markerVI, Boehringer Mannheim). 


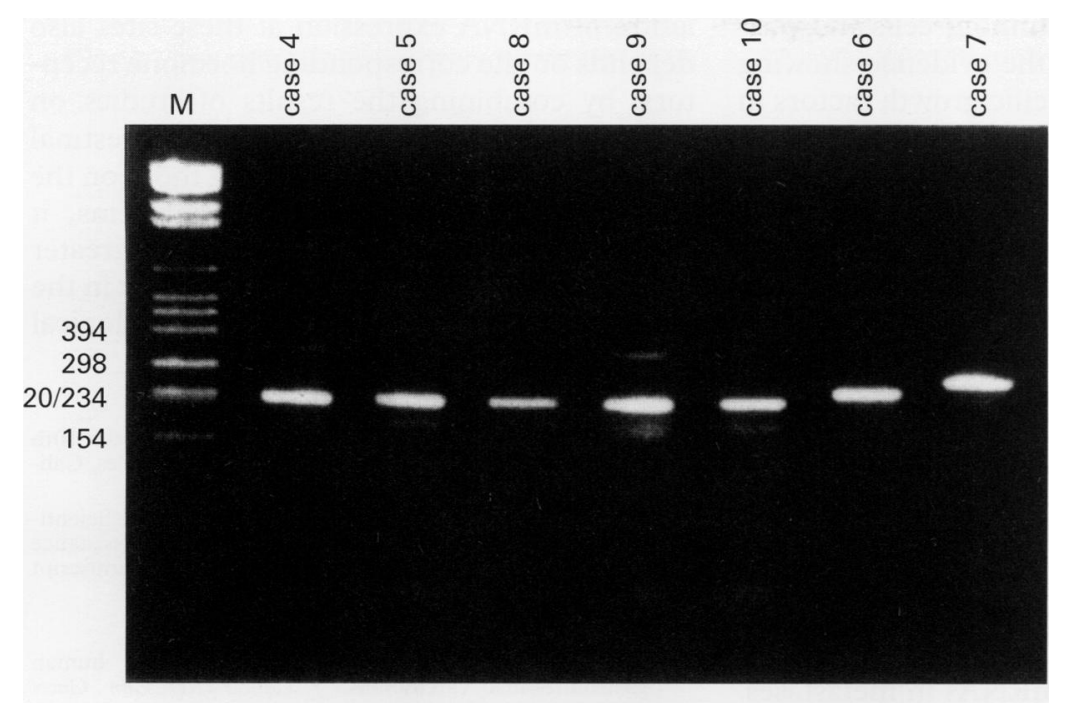

SOMATOSTATIN (nested PCR) in hepatic metastasis

Figure 3 Somatostatin $m R N A$ detected by nested PCR amplification of samples of hepatic metastases. Positive results for cases 6 and 7 were obtained only on reuse of primers 1 and 2 with the nested PCR procedure.

lines and experimental pancreatic cancers, ${ }^{32}$ it is also possible that $\mathrm{CCK}$ may be involved in the carcinogenesis of colorectal carcinomas. Studies of somatostatin have focused mainly on detecting the receptor subtypes in neuroendocrine tumours of various kinds ${ }^{33}{ }^{34}$; to our knowledge no previous studies have been carried out on somatostatin expression in colorectal cancers.

We and other authors have established, using RT-PCR, that gastrin mRNA is expressed in human colon cancer tissue. ${ }^{17-19}$ These findings were confirmed here, as the transcript was detected in nine of the 10 colon cancers investigated. These data suggest that gastrin may act as a colonic tumour growth factor. It is worth noting that the negative PCR sample (case 5) was a rather special case of colonic adenocarcinoma, which had developed after ureterostomy. Somatostatin was expressed in each of the tumours investigated, but the levels of its mRNA were low compared with those recorded in normal colonic tissues, the detection of the transcript being restricted to the second round of PCR. It is possible that the differences between levels of expression observed may explain the high expression of gastrin in tumours, which might be due to a decrease in the down regulation exerted by somatostatin on gastrin expression ${ }^{35}$; it is also possible that other regulatory processes may operate in the case of tumoral tissues.

The data obtained in the present study on the expression of CCK and TGF $\alpha$ mRNA are both informative and intriguing. Thus, the patterns of expression of these two transcripts in tumours obviously differ depending on whether they are located in the left versus right/transverse colon: in the latter, both transcripts were expressed quite strongly (CCK 3/5; TGF $\alpha$ 5/5), whereas expression was reduced in the former (CCK 0/5; TGF $\alpha$ 1/5).

Moreover, the patterns of Grimelius and chromogranin A staining revealed that endocrine cells were present in the three tumoral samples originating from the right colon and not in any of the others. These data suggest that a region specific transcriptional mechanism may be exist, based on genetic differences between the tumour tissue on the right and left sides of the colon, ${ }^{36-38}$ and reinforces the hypothesis that different tumorigenic mechanisms may be involved in carcinomas of the proximal and distal colon, which was previously suggested based on studies of allelic losses $^{39}$ and microsatellite instability. ${ }^{40}$

Immunohistochemistry results indicate either that translational attenuation may occur in neoplastic cells, or that these cells may release unprocessed or poorly processed precursor products, as demonstrated recently for gastrin. ${ }^{41}$ Indeed, these products, which are frequently not carboxyamidated, are not detected in conventional radioimmunoassays targeting the main antral form of carboxyamidated gastrin.

The last point worth mentioning is that on analysis of the basal gastrinaemia associated with the clinical data discussed here there was no correlation between this parameter and the patterns of expression of the transcripts in question. It should be noted, however, that our measurements were carried out using a routine procedure with a standard commercial radioimmunoassay kit which recognised $\mathrm{G} 17$ and G34 equally, ${ }^{18}$-that is, the main antral forms of carboxyamidated gastrins, and which may not have been sensitive enough, as mentioned above, to detect any differences in the processing and release of the immature forms of gastrin into the bloodstream. ${ }^{41}$

Gastrin mRNA was not detected in normal colonic tissue in the present study, which is in agreement with the results of our previous study, ${ }^{18}$ but not with those obtained by other authors. ${ }^{17} 19$ On the basis of the data we obtained at the two levels of purification achieved with the nested PCR procedure, it can now be stated definitely whether a transcript is present. This obviates the problems concerning the intron, which have systematically arisen in RT-PCR studies of gastrin mRNA. ${ }^{17}$ We have no explanation to offer for the lack of agreement between the above data. Although $G$ cells are known to be the source of gastrin in the human antrum, and to a lesser extent in the duodenum, the cellular source of the gastrin in the human colon has not yet been identified incontrovertibly. ${ }^{17}$

It is also possible that somatostatin may inhibit the expression of gastrin mRNA both indirectly (by inhibiting the stimulatory effects of EGF/TGF $\alpha^{10}$ ) or directly. ${ }^{32}$ Somatostatin mRNA was detected systematically in normal colonic mucosa (where it was detected in many cases at the first PCR-for example, in the antrum and fundus). TGF $\alpha$ and CCK were also expressed in the colon, but less consistently.

Understanding the mechanisms responsible for the development of heterogeneous colon cancers and the processes whereby tumour cells can invade local stroma and spread to distant organs is one of the primary goals of cancer research. It is increasingly clear that the outcome of metastasis depends on continuous 
interactions between the tumour cells and various host related factors: the evidence showing that the role of organ specific growth factors in the development of metastatic cells is based partly on experiments on the effects of organ dependent media on the growth of specific neoplastic cells. ${ }^{42}{ }^{43}$ TGF $\alpha$ is one of the most likely candidate growth factors, as it is a physiological regulator of liver regeneration, operating via an autocrine mechanism. ${ }^{44}$ Production of TGF $\alpha$ by hepatocytes might also play a paracrine role, stimulating the proliferation of adjacent non-parenchymal or tumour cells. ${ }^{45}$ In a previous study, we reported for the first time that gastrin mRNA was present in a hepatic metastasis associated with a colonic tumour. ${ }^{18}$ However, to our knowledge, no studies have been carried out before on the expression of somatostatin and CCK mRNAs in metastases.

The present results confirm that $\mathrm{TGF} \alpha$ $(6 / 7)$ and gastrin (5/7) are both expressed at the mRNA level, and show clearly that somatostatin was expressed consistently (7/7) in all the hepatic metastatic samples. It is worth noting that two samples were found to have shorter PCR products than expected; this was probably due to splicing of the mRNA rather than to gene deletion, as the PCR carried out on the corresponding DNA always yielded the same amplification product $\left(1225 \mathrm{bp}^{24}\right.$ ) (data not shown). It is not easy to explain these alterations. Correlations with clinical data obtained on a small number of cases have tentatively indicated that shorter PCR products are associated with a poor prognosis, but further studies are required to determine whether this is actually so. Although CCK mRNA was also detected, its expression seems to be much reduced (1/7).

Therefore, gastrin, $\mathrm{TGF} \alpha$ and somatostatin are expressed in hepatic metastases, but the patterns of expression in these tumours, where the CCK mRNA levels are very low in comparison with those of the three other transcripts, differ conspicuously from those observed in the present study in the normal and tumoral colon.

In previous studies, the coexpression of gastrin and $\mathrm{TGF} \alpha^{14}$ and that of gastrin and $\mathrm{CCK}^{16}$ has been reported in the colon and gastric cancer cell lines. In the present study, the four mRNAs (gastrin, somatostatin, CCK and TGF $\alpha$ ) were likewise found to be coexpressed in the four colon cell lines. However, mRNAs expressed in cell lines are not expressed consistently in the human pathology. No such consistent correlations were observed in the human colon adenocarcinoma samples. Although the cell line model can provide information about the expression of the various mRNA transcripts, it cannot be perfectly representative of what takes place in human pathology. This makes the results of studies on surgical samples correlated with exact clinical data all the more valuable.

In conclusion, the data presented herein shed some light on the transcriptional events involved in the production of the various hormones present in the gastrointestinal tract, in both healthy and tumoral tissues. The regu- lation of mRNA expression at these sites also depends on the corresponding hormone receptors; by combining the results of studies on mRNAs encoding the main gastrointestinal hormones and their receptors with those on the expression of the corresponding proteins, it should be possible to understand in greater detail the regulatory mechanisms at work in the digestive tract and the associated pathological conditions.

A preliminary report on this study was presented at the 10th World Congress of Gastroenterology held in Los Angeles, California, USA, 2-7 October 1994.

This work was supported by grants from the Comite Scientifique de la Faculté de Médecine de Marseille and the Assistance Publique de Marseille. The English version of the manuscript was revised by Dr Jessica Blanc.

1 Tahara E. Growth factors and oncogenes in human gastrointestinal carcinomas. $\mathcal{F}$ Cancer Res Clin Oncol 1990;116:121-31

2 Walsh JH. Gastro-intestinal hormones: past, present, and future. Gastroenterology 1993;104:653-7.

3 Johnson LR. Gastrointestinal hormones and their functions. Ann Rev Physiol 1977;39:135-58.

4 Sirinek KR, Levine BA, Moyer MP. Pentagastrin stimulates in vitro growth of normal and malignant human colon epithelial cells. Am $\mathcal{F}$ Surg 1985;149:35-8.

5 Winsett OK, Townsend CM, Glass EJ, Thompson JC. Gastrin stimulates growth of colon cancer. Surgery 1986; 99:302-7.

6 Smith JP, Solomon TE. Effects of gastrin, proglumide, and somatostatin on growth of human colon cancer. Gastroen terology 1988;95:1541-8.

7 Hoosein NM, Kiener PA, Curry RC, Brattain MG Evidence for autocrine growth stimulation of cultured colon tumor cells by a gastrin cholecystokinin-like peptide. Exp Cell Res 1990;186:15-21.

8 Lamers C, Jansen J. Role of gastrin and cholecystokinin in tumours of the gastrointestinal tract. Eur $\mathcal{F}$ Cancer Clin Oncol 1988;24:267-73.

9 Godley JM, Brand SJ. Regulation of the gastrin promoter by epidermal growth factor and neuropeptides. Proc Nat Acad Sci USA 1989;86:3036-40.

10 Bachwich D, Merchant J, Brand SJ. Identification of a cis-regulatory element mediating somatostatin inhibition of epidermal growth factor-stimulated gastrin gene transcription. Mol Endocrinol 1992;6:1175-84.

11 Beglinger $C$, Hildebrand $P$, Meier R, Bauerfeind $P$, Hasslocher $\mathrm{H}$, Urscheler $\mathrm{N}$, et al. A physiological role for cholecystokinin as a regulator of gastrin secretion. Gastrocholecystokinin as a regulator

12 Herzing KH, Louie DS, Owyang C. Somatostatin inhibits CCK release by inhibiting secretion and action of CCK-releasing peptide. Am F Physiol 1994;266:G115661 .

13 Malden T, Novak U, Burgess AW. Expression of transforming growth factor $\alpha$ messenger RNA in the normal and neoplastic gastro-intestinal tract. Int $\mathcal{f}$ Cancer 1992; 43:380-4

14 Baldwin GS, Zhang OX Measurement of gastrin and TGF $\alpha$ messenger RNA levels in colonic carcinoma cell TGF $\alpha$ messenger RNA levels in colonic carcinoma cell lines by quantitative

15 Sizeland A, Burgess AW. Anti-sense transforming growth factor $\alpha$ oligonucleotides inhibit autocrine stimulated proliferation of a colon carcinoma cell line. Mol Cell Bio 1992;3:1235-43.

16 Van Solinge WW, Rehfeld JF. Co-transcription of the gastrin and cholecystokinin genes with selective translation of gas-
trin mRNA in a human gastric carcinoma cell line. FEBS Lett 1992;309:47-50.

17 Finley GG, Koski RA, Melhem MF, Pipas JM, Meisler AI Expression of the gastrin gene in the normal human colon Expression of the gastrin gene in the normal human colon
and colorectal adenocarcinoma. Cancer Res 1993; and colorectal

18 Monges G, Biagini P, Cantaloube JF, Chicheportiche C, Frances V, Brandini D, et al. Detection of gastrin messenger RNA in fresh human colonic carcinomas by reverse transcription-polymerase chain reaction. $\mathcal{F}$ Mol Endocrinol 1993;11:223-9.

19 Van Solinge WW, Nielsen FC, Friis-Hansen L, Falkmer UG, Rehfeld JR. Expression but incomplete maturation of progastrin in colorectal carcinomas. Gastroenterology 1993 104: 1099-107.

20 Biagini P, Monges G, Cantaloube JF, Parriaux D, Hassoun J, Chicheportiche C. Detection of gastrin mRNA in paraffin-embedded samples of normal antral mucosae using polymerase chain reaction technique. APMIS 1994; using polymera

21 Astler VB, Coller FA. The prognostic significance of direct extension of carcinoma of the colon and rectum. Ann Surg 1954;139:846-51.

22 Chomczynski P, Sacchi N. Single step method of RNA isolation by acid guanidinium thiocyanate-phenol-chloroform extraction. Anal Biochem 1987;162:156-9. 
23 Kariya Y, Kato K, Hayashazaki Y, Himeno S, Tarui S, Matsubara $\mathrm{K}$. Expression of human gastrin gene in normal and gastrinoma tissues. Gene 1986;50:345-52.

24 Shen LP, Rutter WJ. Sequence of the human somatostatin I gene. Science 1984;224:168-71.

25 TakahashiY, Fukushige S, Murotsu T, Matsubara K. Structure of human cholecystokinin gene and its chromosomal location. Gene 1986;50:353-60.

26 Derynck R, Roberts AB, Winckler ME, Chen EY, Goeddel DV. Human transforming growth factor- $\alpha$ : precurso structure and expression in E. coli. Cell 1984;38:287-97.

$27 \mathrm{Kwok}$ C, Higuchi R. Avoiding false positives with PCR. Nature 1989;320:237-8.

28 Sambrook J, Fritsch EF, Maniatis T. Molecular cloning: a laboratory manual. 2nd edn. Cold Spring Harbor: Cold Spring Harbor Laboratory Press, 1989.

29 Watson SA, Durrant LG, Crosbie JD, Morris DL. The in vitro growth response of primary human colorectal and gastric cancers cells to gastrin. Int $\mathcal{f}$ Cancer 1989; 43:692-6.

30 Markowitz SD, Molkentin K, Gerbic C, Jackson J, Stellato $\mathrm{T}$, Willson JKV. Growth stimulation by coexpression of transforming growth factor- $\alpha$ and epidermal growth factor-receptor in normal and adenomatous human colon epithelium. F Clin Invest 1990;86:356-62.

31 Ziober BL, Willson JKV, Humphrey LE, Childress-Fields K, Brattain MG. Autocrine transforming growth factor- $\alpha$ is associated with progression of transformed properties in human colon cancer cells. f Biol Chem 1993;268:691-8.

32 Rehfeld JR, Van Solinge WW. The tumor biology of gastrin and cholecystokinin. Adv Cancer Res 1994;63:295-347.

$33 \mathrm{Kvols} \mathrm{LK}$. Somatostatin-receptor imaging of human malignancies: a new era in the localization, staging, and nancies: a new era in the localization, staging, and

34 Reubi JC, Krenning E, Lamberts SWJ, Kvols L. In vitro detection of somatostatin receptors in human tumors. Digestion 1993;54(Suppl 1):76-83.
35 Karnik PS, Wolfe MM. Somatostatin stimulates gastrin mRNA turnover in dog antral mucosa. F Biol Chem 1990; 265:2550-5.

36 Delattre O, Olschwang S, Law DJ, Melot T, Remvikos Y Salmon RJ, et al. Multiple genetic alterations in distal and proximal colorectal cancer. Lancet 1989;ii:353-5.

37 Remvikos Y, Tominaga O, Hammel P, Laurent-Puig P, Salmon RJ, Dutrillaux B, et al. Increased p 53 protein content of colorectal tumors correlates with poor survival. $\mathrm{Br}$ $\mathcal{f}$ Cancer 1992;66:758-64.

38 Hamelin R, Laurent-Puig P, Olschwang S, Jego N, Asselain $\mathrm{B}$, Remvikos $\mathrm{Y}$, et al. Association of $\mathrm{p} 53$ mutations with short survival in colorectal cancer. Gastroenterology 1994; 106:42-8.

39 Lino H, Fukayama MD, Yoshiharu M, Koike M, Mori T, Takahashi $T$, et al. Molecular genetics for clinical management of colorectal carcinoma. Cancer 1994;73:1324-31.

40 Thibodeau SN, Bren G, Schaid D. Microsatellite instability in cancer of the proximal colon. Science 1993;260:816-19.

41 Ciccotosto GD, McLeish A, Hardy KJ, Shulkes A. Expression, processing, and secretion of gastrin in patients with colorectal carcinoma. Gastroenterology 1995; 109: 1142-53.

42 Morikawa K, Walker SM, Nakajima M, Pathak S, Jessup JM, Fidler IJ. Influence of organ environment on the growth, selection, and metastasis of human colon carcinoma cells in nude mice. Cancer Res 1988;48:6863-71.

43 Fidler IJ. Critical factors in the biology of human cancer metastasis: Twenty-eight G.H.A. Clowes Memorial Award lecture. Cancer Res 1990;50:6130-8.

44 Mead JE, Fausto N. Transforming growth factor- $\alpha$ may be a physiological regulator of liver regeneration by means of an physiological regulator of liver regeneration by means of an 86:1558-62.

45 Derynck $R$. The physiology of transforming growth factor- $\alpha$. Adv Cancer Res 1992;58:27-52. 